\title{
The effect of professional commitment and ethical consideration on the desire to do whistleblowing with locus of control as a moderating variable (study on the banking sector in Palembang)
}

\author{
Inten Meutia; Mohamad Adam; Tiara Nurpratiwi* \\ Dept. of Accounting, Post Graduated Program, Universitas Sriwijaya, Indonesia \\ *To whom correspondence should be addressed. Email: tnurpratiwi@ gmail.com
}

\begin{abstract}
This study aims to obtain empirical evidence regarding the effect of professional commitment and ethical considerations on the desire to conduct whistleblowing. This study also adds locus of control as a moderating variable that influences the relationship between professional commitment and ethical considerations. Respondents in this study were 53 internal auditors placed in the banking operational unit in Palembang and sampling by saturated sample method. The results of this study indicate: (1) The professional commitment of internal auditors has a positive effect on the desire to conduct whistleblowing, (2) Ethical considerations of internal auditors have a positive effect on the desire to conduct whistleblowing, 3) professional commitment of internal auditors moderated Locus of control does not affect desire do whistleblowing, and 4) ethical considerations of internal auditors moderated locus of control does not affect the desire to do whistleblowing.
\end{abstract}

Keywords: ethical considerations, locus of control, professional commitment, whistleblowing

JEL Classification: G20, M42, M14

\section{INTRODUCTION}

The need for the application of a business that not only prioritizes profit, but also people and planets that continue to increase. An organization is required to be able to improve the quality of financial reporting with ethical and effective internal controls. The internal control system (SPI) is needed by internal and external parties of the organization. Internal parties need SPI to prevent irregularities, while external parties, especially external auditors, require SPI in carrying out audits.

Management is the party responsible for designing and implementing SPI. However, the complexity of the organization's operational activities makes management need a new function / department called internal audit. Internal audit is an independent assessment function formed within the company to examine and evaluate its activities as services provided to companies (Sawyers, 2005).

The internal audit function is an integral part of internal control. Through effective internal control, organizational and financial goals can be achieved. Therefore, a system is needed to convey wrongdoing, even fraud that occurs within the organization. Based on the results of a survey conducted by the Association of Certified Fraud Examiners (ACFE) in 2016 categorizing cases of fraud / fraud based on the banking and financial services industry, government and public administration, and manufacturing is the sector most represented in cases of fraud / fraud (fraud ) Being a whistle-blower is not an easy matter. Someone who comes from an internal organization 
will generally face an ethical dilemma in deciding whether to "blow the whistle" or keep it hidden.

Internal factors and external factors influence the actions of individuals to conduct information providers. Internal auditors, especially in matters of internal control, work to provide added value to the organization. Internal auditors are professions that play an important role in a company. The internal auditor acts as an independent appraiser to verify the company's activities by measuring and evaluating the adequacy of controls and the efficiency of the company's activities. Therefore, internal auditors are very useful for managers to improve company performance and achieve company goals. Similarly, if it is about disclosure of information, the first auditor is expected to be the first party to determine whether there is a red flag that is unethical or fraudulent.

The study was carried out at the same scope by Taylor and Curtis (2010) on bigfour external supervisors in the United States, based on the concept of the theory of impact at work. In this different analysis, Taylor and Curtis have determined that professional identity (professional commitment), commitment and moral intensity have a significant impact on intention to learn, and that accountability and continuity of reporting are assessed.

Chiu (2003) conducted a study of MBA students who worked as executives and professionals in China and examined their intentions to control the impact of ethical considerations and establish moderate locus of control. Chiu found that people tend to falter when they think this is the right thing. Individuals with internal locus of control will act when they see violations and commit to enlightenment, but people with external locus of control will not sue because they feel that it is not the responsibility itself. Based on the background described, the author raises title, "The effect of professional commitment and ethical consideration on the desire to do whistleblowing with locus of control as a moderating variable (in Banking Sector in Palembang)".

\section{LITERATURE REVIEW AND HYPOTHESIS}

\section{Attribution theory}

The behavior of each individual is of course based on various reasons or motives underlying the emergence of these behaviors. Some explanations for reasons or reasons are explained using quote theory (Gibson et al., 1996). This theory explains how to evaluate human behavior both internally and externally (Robbins and Judge, 2008).

\section{Theory of planned behavior}

Theory of Planned Behavior (TPB) is a theory that explains whistleblowing intentions, in this case the actions taken are based on very complex psychological processes (Gundlach et al., 2003).

\section{Effect of professional commitment on the desire to do whistleblowing}

Professional commitment is defined as the strength or strength of identity and participation in an organization or work. Professional commitment is the love and loyalty of a person to his profession (Aranya, 1981). Kaplan and Whitecotton (2001) found a positive relationship between professional involvement and auditor demand for inquiry; Accountants with high professional commitment are more likely to provide information. In line with the fact that Smith and Hall (2008) and (Joneta, 2016) have a significant impact on professional commitment and the desire to whistle. Similarly, (Nugraha, 2017) states that professional commitment affects the desire to create awareness. Taylor and Curtis (2010) found a positive relationship between professional commitment (CA auditor) and unprecedented predictive probability. Auditors because of professional dedication, you can determine the fraud that occurs in the company. 
Professional commitment is related to the desire to create a bulletin, there are signs that auditors who are more vulnerable to the profession are more likely to raise awareness. This result is ideal because high professional commitment must encourage auditors to act in accordance with their responsibilities. Thus, the hypothesis can be formulated as follows:

$\mathrm{H}_{1}$ : Professional commitment of internal auditors influences the desire to do whistleblowing.

\section{Effect of ethical considerations on the desire to do whistleblowing}

In (Chiu, 2003) In addition to professional commitment, ethical considerations are a factor that someone will do whistleblowing, namely by finding a positive relationship between ethical considerations and the desire to conduct whistleblowing. This research is in line with Taylor and Curtis (2010). Likewise in (S. Ahmad, Smith, Ismail, Ahmad, and Smith, 2012) towards auditors in Malaysia, that ethical considerations have a positive and significant relationship to internal whistleblowing.

So it can be concluded that someone with high ethical considerations will disclose fraud so that the hypothesis can be formulated as follows:

$\mathrm{H}_{2}$ : Ethical considerations of internal auditors influence the desire to do whistleblowing.

The influence of locus of control in moderating professional commitment to the desire to do whistleblowing

According to Lord and DeZoort (2011) auditors with high professional commitment will behave in harmony with the public interest and will not damage their professionalism. Likewise (Wawo et al., 2015) in his research states that professional commitment can moderate the influence of experience on auditor ethical considerations in making decisions. According to (Nasution and Östermark, 2012), professional commitment is one factor that has the potential to influence auditor behavior in determining ethical considerations.

In (Purwantini, Waharini, and Anisa, 2017) states that the higher the level of self efficacy associated with the internal locus of control of employees, the intention to report fraud in the company will increase. With the interaction between professional commitment and Locus of control, the auditor is expected to be able to make decisions about his desire to conduct whistleblowing. So the hypothesis can be formulated as follows:

$\mathrm{H}_{3}$ : Locus of control moderates the professional auditor's internal commitment to the desire to do whistleblowing.

\section{Effect of locus of control in moderating ethical considerations towards the desire to do whistleblowing}

Locus of control is one of the individual variables that can be used to estimate behavior or actions carried out by someone. As an argument, (Nasution and Östermark, 2012) states that Locus of Control influences auditor decisions. Another study (Dali et al., 2017) states that the Chamber of Control and Organizational Culture has a positive and significant effect on auditors when making ethical decisions simultaneously. Jalil (2012) states that auditors with independent and ethical locus of control. Therefore, if someone is connected with his profession and has an internal locus of control, he has more intention to enlighten (Taylor and Curtis, 2010).

Ethical problems that are controlled by locus of control can affect the willingness of internal auditors to practice together. Individuals with internal locus of control are more consistent between moral judgment and moral action, and evaluation of actions that disclose information is ethical. Thus, the hypothesis can be formulated as follows:

$\mathrm{H}_{4}$ : Locus of control moderates the Ethical Considerations of internal auditors towards the desire to do whistleblowing. 


\section{RESEARCH METHODS}

The population in this study is that all internal auditors working in the operational work units of banks that have a network in Palembang consisting of 50 banks, the position of January 2018 there are 53 internal audits in 23 branches in 16 types of banks. The sampling technique in this study is saturated samples. The data collection technique is using primary data with questionnaires. The number of questionnaire distributions based on the number of Banks in Palembang that accept to be respondents is that there are 16 banks, each of which is distributed as many as the number of internal auditors placed in the work unit.

The method of data analysis used is multiple linear regression and moderate regression analysis. Measurement the desire to conduct whistleblowing in this study was measured using a scenario developed by Sagara (2013). Professional commitment variables were measured using the Allen and Meyer (1991) questionnaire with 20 questions. The ethical considerations variable in this study using a scenario from Aai (2013). The locus of control variable is measured using an instrument developed by Spector (1988).

The testing model used to test the hypothesis in this study also uses multiple regression analysis and moderation regression analysis. The equations used are as follows:

Information:

$$
\begin{gathered}
Y=\alpha+\beta_{1} X_{1}+\beta_{2} X_{2}+e \\
Y=\alpha+\beta_{1} X_{1}+\beta_{2} X_{2}+\beta_{3} X_{3}+\beta_{4} X_{1} X_{3}+\beta_{5} X_{2} X_{3}+e
\end{gathered}
$$

$\mathrm{Y} \quad=$ The desire to do Whistleblowing

$\alpha \quad=$ Constants

$\beta_{1}, \beta_{2}, \beta_{3}, \beta_{4}, \beta_{5}=$ Regression Coefficient

$\mathrm{X}_{1} \quad=$ Professional Commitment

$\mathrm{X}_{2} \quad=$ Ethical Considerations

$\mathrm{X}_{3} \quad=$ Locus of Control

$\mathrm{e} \quad=$ Error

\section{RESULTS AND DISCUSSION}

All questionnaires distributed were 53 questionnaires. Questionnaires returned were 53 questionnaires (100\%), questionnaires that could be processed were 52 questionnaires $(98.12 \%)$, and 1 questionnaire (1.88\%) could not be processed because the answer was incomplete. The profile of all respondents based on the type of bank where the respondent works is dominated by Private Banks, which are 27 respondents (51\%), while from BUMN Banks there are 15 respondents $(28 \%)$ and the last from BUMD Banks have the lowest percentage of 11 respondents $(21 \%)$.

.Validity test. Obtained results that $r_{\text {table value of } 0.2732 \text { and }} r_{\text {count }}>r_{\text {table }}$ so that all questions for the variable desire to do whistleblowing, professional commitment, ethical consideration and locus of control can be said to be valid.

Reliability test results. The results of the calculation of the reliability correlation coefficient for each study variable using the Cronbach Alpha method show the cronbach's alpha value for each variable above 0.6. Thus it can be said that all the research variables are close to one so it is declared reliable and can be used as a research instrument.

Classical assumption test results. From the results of the calculation of the regression model this study fulfills the assumptions of normality, is free from multicollinearity, and does not occur heterocedasticity. 


\section{Analysis of multiple linear regression}

The estimation on the influence of professional commitment and ethical considerations on desire to do whistleblowing are shown in Table 1.

Table 1. Results of Multiple Linear Regression Analysis

\begin{tabular}{lcccc}
\hline \multirow{2}{*}{ Model } & \multicolumn{2}{c}{ Unstandardized Coefficients } & \multirow{2}{*}{ T } & \multirow{2}{*}{ Sig. } \\
\cline { 2 - 3 } & B & Std. Error & & .746 \\
\hline (Constant) & .327 & .749 & .665 \\
Professional Commitment & .099 & .022 & 4.412 & .000 \\
Ethical Considerations & .317 & .070 & 4.512 & .000 \\
\hline
\end{tabular}

a. Dependent Variable: whistleblowing

$$
\mathrm{Y}=\mathbf{0 , 3 2 7}+\mathbf{0 , 0 9 9} \mathrm{X}_{1}+\mathbf{0 , 3 1 7} \mathrm{X}_{2}
$$

\section{Moderate Regression Analysis}

The estimation on the influence of professional commitment, ethical considerations, locus of control, moderation1 variables (professional commitment $\mathrm{x}$ locus of control) and moderation2 (ethical consideration $\mathrm{x}$ locus of control) on desire to do whistleblowing are shown in Table 2.

Table 2. Results of moderation regression analysis

\begin{tabular}{lrcrc}
\hline \multirow{2}{*}{ Model } & \multicolumn{2}{c}{ Unstandardized Coefficients } & \multirow{2}{*}{$\mathrm{T}$} & \multirow{2}{*}{ Sig. } \\
\cline { 2 - 3 } \multicolumn{1}{c}{ B } & Std. Error & & \\
\hline (Constant) & -11.719 & 5.704 & -2.054 & .046 \\
Professional Commitment & -.128 & .192 & -.664 & .510 \\
Ethical Considerations & 1.523 & .599 & 2.543 & .014 \\
Locus of control & .247 & .118 & 2.083 & .043 \\
Moderation1 & .005 & .004 & 1.163 & .251 \\
Moderation2 & -.024 & .012 & -2.018 & .049 \\
\hline a. Dependent Variable: whistleblowing & & & &
\end{tabular}

$$
Y=-11.719-0.128 X_{1}+1.523 X_{2}+0.247 X_{3}+0.005 X_{1} * X_{3}-0.024 X_{2} * X_{3}
$$

It is known that $\mathrm{F}_{\text {table }}$ is 2.79 and the value of $\alpha=0.05$, which is $0.00<\alpha=0.05$, then the hypothesis is accepted. This can be said that the variables of professional commitment and ethical considerations of internal auditors have a significant effect on the variable desire to do whistleblowing (Table 3).

Table 3. F test results

\begin{tabular}{lcc}
\hline Model & $\mathrm{F}$ & Sig. \\
\hline $1 \quad$ Regression & 144.751 & $.000^{\mathrm{b}}$
\end{tabular}

\section{Coefficient of Determination ( $R^{2}$ Test)}

The coefficient of determination shows the percentage of the variation in the value of the independent variable that can be explained by the regression equation produced. The coefficient of determination is as follows:

Table 4. Second determination coefficient test results

\begin{tabular}{lccc}
\hline Model & $\mathrm{R}$ & $\mathrm{R}$ Square & Adjusted R Square \\
\hline 1 & $.936^{\mathrm{a}}$ & .877 & .864 \\
\hline a. Predictors: (Constant), Moderasi2, Locus of control, Professional Commitment, Ethical \\
Considerations, Moderation1
\end{tabular}

Based on the calculation of the value of determination coefficient obtained the adjusted $\mathrm{R}^{2}$ is 0.864 or $86.4 \%$. This means that the ability of professional commitment 
variables, ethical considerations and locus of control (moderating variables) to desire whistleblowing is $86.4 \%$ while the remaining $13.6 \%$ is explained by other variables not observed in this study.

\section{The effect of professional commitment on the desire to do whistleblowing with locus of control as a moderating variable}

Based on the results of data processing can be seen the influence of locus of control to moderate the relationship between professional commitment of internal auditors in realizing the desire to do a whistleblowing as follows:

Table 5. The results of moderating $X_{3}$ with $X_{1}$

\begin{tabular}{lrrrr}
\hline \multirow{2}{*}{ Model } & \multicolumn{2}{c}{ Unstandardized Coefficients } & \multirow{2}{*}{$\mathrm{T}$} & \multirow{2}{*}{ Sig. } \\
\cline { 2 - 3 } & \multicolumn{1}{c}{$\mathrm{B}$} & Std. Error & & \\
\hline (Constant) & -10.136 & 6.900 & -1.469 & .148 \\
Professional Commitment & .338 & .097 & 3.504 & .001 \\
Locus of control & .233 & .143 & 1.630 & .110 \\
Moderation1 & -.003 & .002 & -1.581 & .120 \\
\hline
\end{tabular}

a. Dependent Variable: whistleblowing

Based on Table 5 the results of the analysis of Moderated Regression Analysis (MRA), the moderating variable is the interaction between the professional commitment of internal auditors with locus of control $\left(\mathrm{X}_{3} * \mathrm{X}_{1}\right)$. The output results above show that the value of $t_{\text {count }}$ is known for the professional commitment variable $\left(\mathrm{X}_{1}\right)$ which is moderated by Locus of control $\left(\mathrm{X}_{3}\right)$ of -1.581 and the value of sig. $0.120>\alpha=0.05$, this means that the moderating variable $\left(\mathrm{X}_{3} * \mathrm{X}_{1}\right)$ is not significant at the $5 \%$ level so this study cannot accept $\mathrm{H}_{3}$.

\section{The effect of ethical considerations on the desire to do whistleblowing with locus of control as a moderating variable}

Based on the results of data processing can be seen the influence of locus of control to moderate the relationship between ethical considerations of internal auditors in realizing the desire to do a whistleblowing as follows:

Table 6. The results of moderating $\mathrm{X}_{3}$ with $\mathrm{X}_{2}$

\begin{tabular}{lrrrr}
\hline \multirow{2}{*}{ Model } & \multicolumn{2}{c}{ Unstandardized Coefficients } & \multirow{2}{*}{ T } & \multirow{2}{*}{ Sig. } \\
\cline { 2 - 3 } & \multicolumn{1}{c}{$\mathrm{B}$} & \multicolumn{1}{c}{ Std. Error } & & \\
\hline (Constant) & -14.483 & 6.524 & -2.220 & .031 \\
Ethical Considerations & 1.247 & .289 & 4.324 & .000 \\
Locus of control & .326 & .135 & 2.418 & .019 \\
Moderation2 & -.014 & .006 & -2.274 & .027 \\
\hline
\end{tabular}

a. Dependent Variable: whistleblowing

Based on the results of the analysis of Moderated Regression Analysis (MRA) in Table 6, the moderating variable is the interaction between ethical considerations of internal auditors with locus of control $\left(\mathrm{X}_{3} * \mathrm{X}_{2}\right)$. The output results above show that it is known that the $t_{\text {count }}$ for ethical consideration variables $\left(\mathrm{X}_{2}\right)$ which is moderated by Locus of control $\left(\mathrm{X}_{3}\right)$ is -2.274 and sig. $0.120<\alpha=0.05$, this means that the moderating variable $\left(\mathrm{X}_{3} * \mathrm{X}_{2}\right)$ is significant at the $5 \%$ level so that this study can accept $\mathrm{H}_{4}$.

The influence of the internal auditor's professional commitment to the desire to do whistleblowing

From the results of testing the first hypothesis the research proves that the professional commitment variable is significantly positive affecting the variable desire to do whistleblowing. Can be seen in table 1 that $t_{\text {count }}(4.412)>t_{\text {table }}(2.011)$ with a significant value of 0 (zero) with an error rate of $\alpha=0.05$. It can also be proven that the 
regression coefficient (Beta) of 0.474 shows that the direction of influence is positive, namely the higher the professional commitment of the internal auditor, the higher the desire to do whistleblowing.

\section{Effect of ethical considerations on internal auditors on the desire to conduct whistleblowing}

Based on table 1, it can be seen that $t_{\text {count }}(4.512)>t_{\text {table }}(2.011)$ with a significant value of 0 (zero) with an error rate of $\alpha=0.05$. From the results of the test it can be concluded that $\mathrm{H}_{2}$ is accepted, namely there is an influence of ethical considerations on the desire to do whistleblowing. In addition, the test results show that the Beta value is 0.485 , this indicates that the direction of influence is positive, namely the higher ethical considerations held by internal auditors, the higher the desire to do whistleblowing.

The effect of the professional commitment of internal auditors on the desire to conduct whistleblowing which is moderated by locus of control

Based on table 5, it can be seen that $t_{\text {count }}(1.581)<t_{\text {table }}(2.011)$ with a significant value of $0.120>\alpha=0.05$ with a level of error (alpha) 0,05 . From the test results it can be concluded that $\mathrm{H}_{3}$ is rejected, namely the Locus of control variable does not moderate the relationship between professional commitment and the desire to do whistleblowing.

The effect of ethical considerations of internal auditors on the desire to conduct whistleblowing which is moderated by locus of control

Based on table 6 it can be seen that $t_{\text {count }}(2.274)>t_{\text {table }}(2.011)$ with a significant value of $0.027<\alpha=0.05$ with an error rate (alpha) of 0.05 . From the test results it can be concluded that $\mathrm{H}_{4}$ is accepted, that is, Locus of control variable moderates the relationship between ethical considerations and the desire to do whistleblowing.

\section{CONCLUSSIONS AND RECOMMENDATIONS}

\section{Conclusions}

There are some conclusions from the discussion above, the first conclusion is professional commitment has a positive effect on the desire to do whistleblowing, the second conclusion is ethical considerations have a positive effect on the desire to do whistleblowing, the third conclusion is locus of control does not moderate the relationship of professional commitment to the desire to do whistleblowing, and the fourth conclusion is locus of control moderates the relationship of ethical considerations towards the desire to do whistleblowing.

\section{Recommendations}

This study only takes the independent variable professional commitment ethical consideration variable, and locus of control so that it only limits the influence on the desire to do whistleblowing. Therefore, it needs to be developed again for further research by entering other variables which affects the desire to do whistleblowing, so that it gets better results.

\section{REFERENCES}

Ahmad, S., Smith, G. M., \& Ismail, Z. (2012). Internal Whistle-Blowing Intentions: A Study of Demographic\& Individual Factors. Journal of Modern Accounting \& Auditing, 8(11), 1632-1645.

Allen, N.J. dan J.P. Meyer. 1991. "The Measurement and Antecedents of Affective, Continuance and Normative Commitment to the Organizational". Journal of Occupational Psychology. 63 (1): 1-18. 
Chiu, K. R. (2002). "Ethical Judgment, Locus of Control, and Whistleblowing Intention: a case study of mainl\& Chinese MBA students”. Managerial Auditing Journal.

Chiu, K. R. (2003). "Ethical Judgment \& Whsitleblowing Intention : Examining theModerating Role of Locus of Control". Journal of Business Ethics. Vol.43:65-74.

Daivitri, Aai. N. (2013). "Pengaruh Pertimbangan Etis dan Komponen Perilaku Terencana pada Niat Whistleblowing Internal dengan Locus of Control sebagai Variabel Pemoderasi”. Yogyakarta: Program Magister (S2), Universitas Gadjah Mada.

Dali, Nasrullah., Sari, Ika., \& Chaerani, Dewi. (2017). The Influence of Locus of Control \& Cultural Organization Ethical Decision of Auditors (Study on BPKP Representative of Southeast Sulawesi Province). IOSR Journal of Business \& Management. p-ISSN: 2319-7668. Volume 19, Issue 8. Ver. III. PP 23-28.

Gibson, James L. et al. (1996). Organisasi: Perilaku, Struktur, Proses Diterjemahkan oleh Ninuk Adriani. Jakarta: Binarupa Aksara

Gundlach, M.J., Douglas, S.C., \& Martinko, M.J. (2003). "The Decision to the Whistle Blow: A Social Information Processing Framework". The Academy ofManagement Review. Vol. 28 (1):107-123.

Joneta, Chintya. (2016). Pengaruh Komitmen Profesional dan Pertimbangan Etis Terhadap Intensi Melakukan Whistleblowing: Locus Of Control Sebagai Variabel Moderasi. JOM Fekon, Vol.3 No.1. pp. 735-748.

Kaplan, S. E. dan Whitecotton, S. M. (2001). An Examination of Auditor's Reporting Intentions when Another Auditor is offered Client Employment. Auditing: A Journal of Practice \& Theory. Vol. 20 No.1, pp. 45-63.

Nasution, Damai \& Ostemark, Ralf. (2012). The Impact of Social Pressures, Locus of Control \& Professional Commitment on Auditors Judgment. Ulasan Asian Akuntansi, Vol. 20 Issue: 2, pp.163-178.

Nugraha, Taufiq. (2017). Pengaruh Komitmen Profesional, Lingkungan Etika, Sifat Machiavellian dan Personal Cost Terhadap Intensi Whistleblowing Dengan Retaliasi Sebagai Variabel Moderating. JOM Fekon, Vol. 4. (1).; 2030-2044.

Purwantini, Anissa. 2017. Analisis Determinasi Intensi Whistleblowing Internal Studi Pada Industri Di Magelang. ISSN 2407-9189. University Research Colloquium 2017.

Robbins dan Judge. (2008). Perilaku Organisasi, Edisi Duabelas, Penerbit Salemba Empat: Jakarta.

Sagara, Y. (2013). "Profesionalisme Internal Auditor dan Intensi Melakukan Whistleblowing”. Jurnal Liquidity. Vol.2 (1):34-44.

Sawywer, L. B., Dittenhofer, M. A. \& Scheiner, J. H. (2005). Sawyer's Internal Auditing. Buku 1 : Edisi 5. Jakarta : Salemba Empat.

Shawver, T. (2011). "The Effects of Moral Intensity on Whistleblowing Behaviour Accounting Professional" . Journal of Forensic \& Investigate Accounting, Vol. 3 Iss.2.

Taylor, E.Z dan Mary B. Curtis. (2010). “An Examination Of The Layers Workplace Influence In Ethical Judgement: Whistleblowing Likelihood \& Perseverance in Public Accounting”. Journal of Business Ethics, Vol.93, pp. 21-37.

Wawo, A. B., N. A., \& S. N. (2015). The influence of organizational culture, ethical awareness \& experience to ethical judgments auditor through Professional commitment (Study at Inspectorate Sub-Province of Bombana). The International Journal Of Engineering \& Science (IJES), Volume 4, 15 - 25. 